\title{
POPULATION STRUCTURE AND LIFE HISTORY OF NEOMYSIS NIGRA NAKAZAWA, 1910 (MYSIDA) ON JEJU ISLAND, SOUTH KOREA
}

\author{
BY \\ JAE-YONG BAE $^{1}$ ), GYEONG EON NOH ${ }^{2}$ ) and WON-GYU PARK ${ }^{1,3}$ ) \\ 1) Department of Marine Biology, Pukyong National University, Busan 608-737, South Korea \\ ${ }^{2}$ ) Center of Ornamentals, Reefs \& Aquariums, Jeju Island 695-976, South Korea
}

\begin{abstract}
Population structure and life history of the mysid Neomysis nigra Nakazawa, 1910 were studied on Jeju Island, South Korea. N. nigra was collected monthly from a shallow embayment of Jeju Island from May 2013 to May 2014. Temperature and salinity were measured during the sampling. The carapace length (CL) of $N$. nigra was measured. Life stages were divided into six categories and embryos in the marsupium were classified by developmental stages. During the study period, water temperatures ranged from -0.3 to $35.7^{\circ} \mathrm{C}$. The $\mathrm{CL}$ of females was larger than that of males. The mean CL of adults was negatively correlated with water temperature. CL values in winter and spring were higher than those in summer and autumn. Brooding females and juveniles were found all year round. The abundance of juveniles was relatively higher in May, July, December, and February than in other months. The number of embryos in the marsupium increased with increasing female size. In conclusion, the present study suggests that the populations of $N$. nigra have four major spawning groups in a year and reproduce all year round.
\end{abstract}

\section{RÉSUMÉ}

La structure de la population et l'histoire de vie du mysidacé Neomysis nigra Nakazawa, 1910 ont été étudiées dans l'île de Jeju, Corée. $N$. nigra a été collecté mensuellement dans des baies peu profondes de l'île de Jeju de Mai 2013 à Mai 2014. La température et la salinité ont été mesurées au cours de l'échantillonnage. La longueur de la carapace (CL) de $N$. nigra a été mesurée. Le cycle de vie a été divisé en six catégories et les embryons dans le marsupium ont été classés par stade de développement. Au cours de la période étudiée, les températures de l'eau ont varié de $-0,3$ à $35,7^{\circ} \mathrm{C}$. La CL des femelles a été plus grande que celle des mâles. La CL moyenne des adultes a été corrélé négativement avec la température de l'eau. Les valeurs de CL en hiver et au printemps ont été plus élevées que celles en été et en automne. Des femelles en reproduction et des juvéniles ont été trouvés tout au long de l'année. L'abondance des juvéniles a été plus élevée en Mai, Juillet,

\footnotetext{
$\left.{ }^{3}\right)$ Corresponding author; e-mail: wpark@pknu.ac.kr

(C) Won-Gyu Park 2016.
} license, visit http://creativecommons.org/licenses/by/3.0/ or send a letter to Creative Commons, PO Box 1866, 
Décembre et Février que dans les autres mois. Le nombre d'embryons dans le marsupium a augmenté avec la taille croissante des femelles. En conclusion, cette étude suggère que la population de $N$. nigra présente quatre groupes majeurs de ponte par an et se reproduit toute l'année.

\section{INTRODUCTION}

Mysids are highly adaptive crustaceans inhabiting a wide variety of aquatic environments, from fresh waters to saline water (Laprise \& Dodson, 1993; McKenney \& Celestial, 1995). Estuarine and coastal waters have fluctuating gradients of various physicochemical characteristics, that can put estuarine mysids under physiological and ecological stress (Ysebaert \& Herman, 2002). The life history and population structure of mysids are influenced by changing environmental conditions, such as temperature and salinity (Mauchline, 1980).

Water temperature influences various components, such as growth, maturity and reproduction (Mauchline, 1980). Mysids grow and mature rapidly, and have a shorter life span in warm water regions (Toda et al., 1982; Yan, 1982). The number of generations of Neomysis awatschensis (Brandt, 1851) varies depending upon location: six generations in the Akkeshi-ko estuary, Japan (Yamada et al., 2007) and four generations (reported as N. intermedia) in Kasumigaura Lake, Japan (Toda et al., 1982) in a year. The reproduction rate of mysids is correlated with water temperature. Mysids in tropical and subtropical breed continuously, whereas the ones in temperate regions stop breeding in the winter season (Toda et al., 1982; Baldó et al., 2001; Hanamura et al., 2009). The brood size of mysids decreases with decreasing water temperature (Toda et al., 1984).

The salinity also leads to a change in growth rates, maturity and fecundity of mysids (Toda et al., 1984; McKenney \& Celestial, 1995; Fockedey et al., 2005). The number of eggs or larvae of Neomysis japonica Nakazawa, 1910 was smaller in a low salinity environment than in a high salinity environment (Ishikawa \& Oshima, 1951). Body length and daily growth rate of $N$. awatschensis decreased with decreasing salinity (Jee et al., 2001). The members of the genus Neomysis are abundant in the coastal and estuarine environments of the oceans of the world (Mauchline, 1980), probably due to their high tolerance for temperature and salinity (Tattersall \& Tattersall, 1951; Pezzack \& Corey, 1982) and opportunistic omnivorous feeding habits (Fockedey \& Mees, 1999). Neomysis nigra Nakazawa, 1910 is widely distributed in the temperate and subarctic region from 35 to $59^{\circ} \mathrm{N}$ (Ii, 1964; Holmquist, 1973; Petryashev, 2002). Neomysis nigra is a euryhaline and eurythermal mysid (Tattersall \& Tattersall, 1951; Pezzack \& Corey, 1982), a sciaphilic species that commonly lives at shallow depths in estuarine and coastal waters which have fluctuating gradients of physicochemical characteristics such as temperature and salinity (Toda et al., 1983; Ysebaert \& Herman, 2002; Yamada et al., 2007). 
Jeju Island is located in the southern part of Korean waters. An embayment of Ojo-ri, where the research was conducted, is located on the east coast of Jeju Island. This embayment is characterized by warm and eutrophic water conditions and is affected by the Tsushima Warm Current throughout the year (Affan \& Lee, 2004). The water temperature in the embayment is more influenced by air temperature because of the shallow water depth (mean $1.2 \mathrm{~m}$ ) and enclosed geographical features, which are connected to the coastal sea by a narrow channel (Oh, 2004). Fresh water irregularly flows into this area from nearby streams, bringing nutrients into the area so that the productivity of macroalgae and seagrasses, such as Ulva sp. and Zostera marina Linnaeus, 1753, is high (Lee, 2006; Pavlyuk \& Trebukhova, 2011). The macroalgae and seagrasses of the area provide shelters for many fish and crustaceans.

The objectives of present study are to investigate the life-history and the population structure of N. nigra in the Ojo-ri embayment, Jeju Island, South Korea.

\section{MATERIAL AND METHODS}

The embayment of Ojo-ri, Jeju Island is located at $33^{\circ} 27^{\prime} \mathrm{N} 126^{\circ} 54^{\prime} \mathrm{E}$ on the east coast of Jeju Island, South Korea (fig. 1). This embayment is approximately $1.2 \mathrm{~m}$ deep and $1.54 \mathrm{~km}^{2}$ large. The north of the Ojo-ri embayment is connected to the coastal sea by the Seongsan water gate. The bottom of the embayment is mostly muddy.

Neomysis nigra was monthly collected from May 2013 to May 2014 using a hand net (mesh size $500 \mu \mathrm{m}$ ) from approximately 0.3-0.5 m depth. Temperature

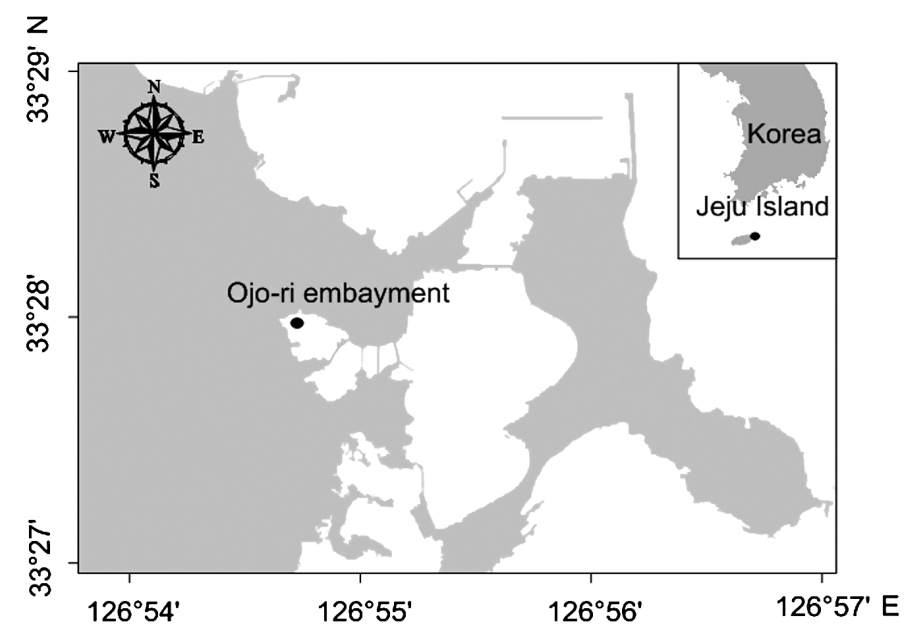

Fig. 1. Sampling location in the Ojo-ri embayment of Jeju Island, South Korea. 
and salinity were simultaneously measured in situ during the sampling. Also, Onset $^{\circledR}$ data loggers (HOBO) were established from July 2013 to May 2014, recording water temperature with recording intervals of $10 \mathrm{~min}$. Specimens were mainly collected at low tide and preserved in $70 \%$ ethanol.

Specimens were identified down to species level and then classified to six demographic categories on the basis of their reproductive and sexual characteristics, following Mauchline (1980): (1) juveniles (JUV) without secondary sexual characteristics; (2) immature males (IM) with developing secondary sexual characteristics ( $4^{\text {th }}$ pleopod); (3) immature females (IF) with undeveloped marsupia; (4) mature males (MM) with completely developed secondary sexual characteristics; (5) mature females (MF) with completely developed secondary sexual characteristics and empty marsupia; and (6) brooding females (BR), corresponding to mature females with eggs or larvae in the marsupium.

Carapace length (CL) measurements were taken under a stereo-microscope equipped with an image analysing system (Olympus SXZ10, Active measure, Japan). CL was measured from the posterior margin of the right eye socket to the mid-point of the posterior margin of the carapace. If there were more than 100 specimens in a sample CL was measured from 100 specimens.

Length-frequency histograms were made with a $0.25 \mathrm{~mm}$ class-size interval, following Sturges' rules (Sturges, 1926). Normality of distributions was tested with a Ryan-Joiner test, using Minitab ${ }^{\circledR} 12.1$ (Minitab, 1998). Histograms were then smoothed with a moving average to rule out non-significant peaks. A modal decomposition of distributions was made according to the Bhattacharya (1967) method, using FISAT II software (FAO, Rome, Italy). The number of modes, means, standard deviation and proportions of mysids were computed.

Sex ratio (number of mature males vs. number of mature females) was examined over the whole sampling period. To identify the difference of relative proportions of both sexes, the $\chi^{2}$ test was used. To determine the size at sexual maturity in both sexes, the proportion of mature individuals (including brooding females for females) by size-class was calculated using the following equation:

$$
P_{\mathrm{i}}=1 /\left(1-\exp \left(a_{\mathrm{i}} \times C L_{\mathrm{i}}+b_{\mathrm{i}}\right)\right)
$$

where $P_{\mathrm{i}}$ is the predicted proportion of mature females $\left(P_{\mathrm{i}}=P_{\mathrm{f}}\right)$ or males $\left(P_{\mathrm{i}}=P_{\mathrm{m}}\right), a_{\mathrm{i}}$ and $b_{\mathrm{i}}$ the estimated coefficients of the logistic equation, and $C L_{\mathrm{i}}$ the carapace length of females $\left(C L_{\mathrm{f}}\right)$ or males $\left(C L_{\mathrm{m}}\right)$. The parameter estimation of this equation was made by correlation analysis of variables $P$ and $C L$ after linearization. Size at sexual maturity $C L_{\mathrm{i}(50)}$ is the carapace length at $50 \%$ sexual maturity, calculated using the following equation (Campbell, 1985):

$$
C L_{\mathrm{i}(50)}=-\left(b_{\mathrm{i}} / a_{\mathrm{i}}\right) .
$$


The number of embryos or larvae in the female marsupium was also counted. Embryonic and larval development was classified into three developing stages, following Wittmann (1981): (1) embryonic stage (no distinguishable appendages), (2) nauplioid stage (thoracic appendages in development) and (3) post-nauplioid stage (thoracic appendages fully developed and distinct stalked eyes). The relationship between brood size and brooding female size was estimated using regression analysis. The brood size and CL of brooding females were natural log-transformed so that the data conform closely with the assumptions of linear regression regarding homogeneity of error variance over the range equation. A linear regression test was used to find the relationship between $\mathrm{CL}$ and brood size using following equation:

$$
\ln (\operatorname{brood} \text { size })=a+b \ln (C L)
$$

where $a$ is the intercept and $b$ the slope.

\section{RESULTS}

\section{Temperature and salinity}

The monthly mean water temperature in situ gradually increased from February $\left(10.1^{\circ} \mathrm{C}\right)$ to June $2014\left(21.2^{\circ} \mathrm{C}\right)$. Then monthly mean water temperature increased rapidly from June $\left(21.2^{\circ} \mathrm{C}\right)$ to July $\left(32^{\circ} \mathrm{C}\right)$, reaching a maximum in August 2013 $\left(32.2^{\circ} \mathrm{C}\right)$. Thereafter, water temperature decreased gradually to January $2014\left(7^{\circ} \mathrm{C}\right)$ (fig. 2A). Water temperature measured by data logger corresponded very well with the water temperature in situ, except for October 2013. However, the water temperature range of the data logger was wider than in situ $\left(-0.27\right.$ to $\left.35.67^{\circ} \mathrm{C}\right)$ (fig. $\left.2 \mathrm{~A}\right)$. The salinity varied with the time of day and sampling month. Water salinity was lowest in March 2014 (6 psu) and highest in July 2013 (28 psu) (fig. 2B).

\section{Demographic and size structure}

Neomysis nigra was found during the entire sampling period, except in September 2013. The relative proportion of demographic categories in the population changed monthly (fig. 3). Brooding females and juveniles were observed throughout the year. The proportion of brooding females was highest in October 2013 (24\%), followed by April 2014 (22\%), May 2013 (18\%) and June 2013 (17\%). The proportion of juvenile was highest in May 2014 (37\%), followed by December 2013 (31\%), March 2014 (26\%), February 2014 (24\%) and July 2013 (16\%). Four spawning groups were produced per year, reproducing in May, July, December and February, respectively.

The mean CL of females was larger than that of males $(t=2.11 ; p<0.05)$ (fig. 4). The mean CL of adult females and males was the largest in January and 


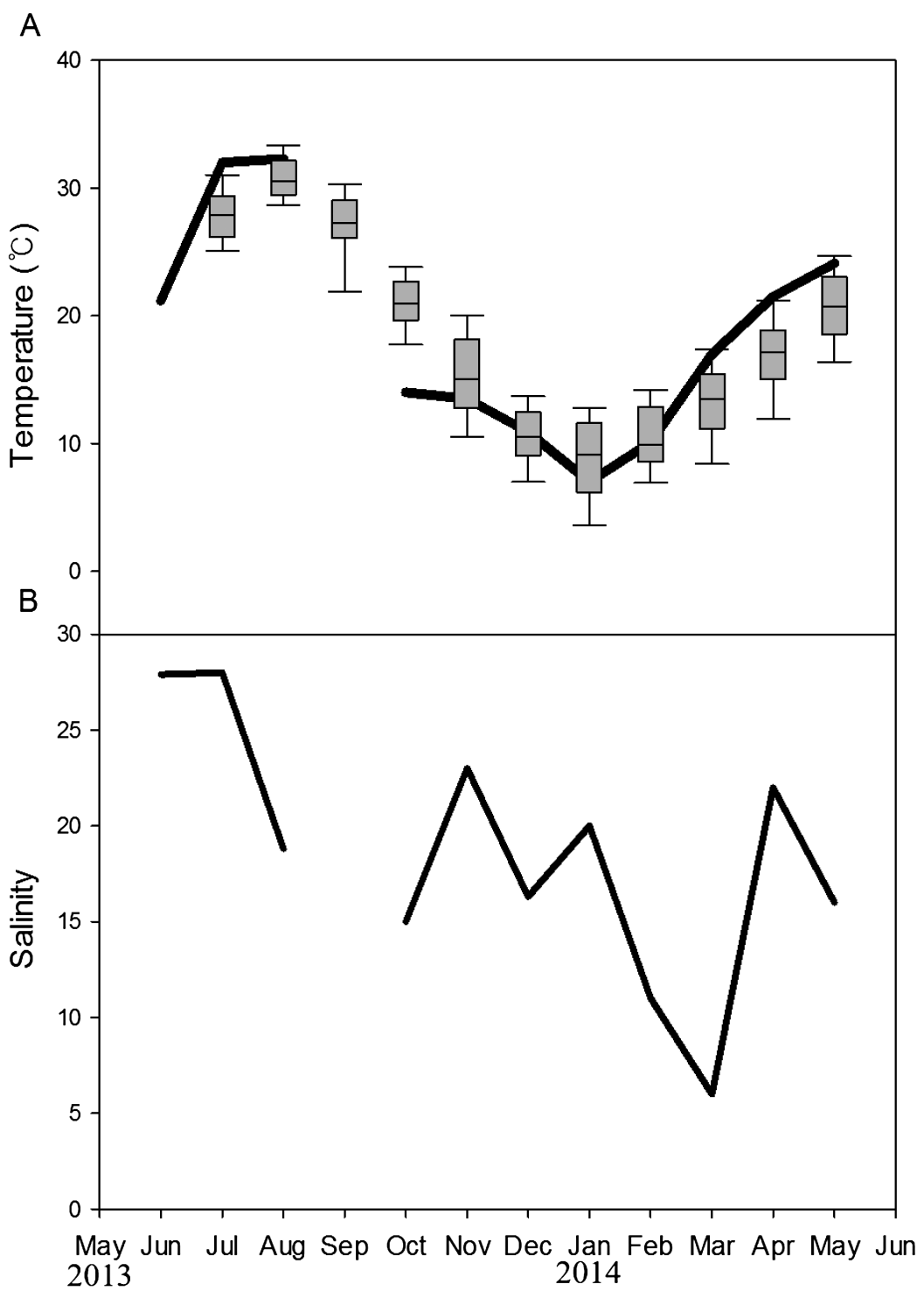

Fig. 2. Temperature (A) and salinity (B) in the Ojo-ri embayment of Jeju Island, South Korea. Black solid line, sampling site; box plot, data logger.

December (female $2.340 \pm 0.029 \mathrm{~mm}$, male $2.084 \pm 0.059 \mathrm{~mm}$ ), while it was the smallest in August (female $1.676 \pm 0.025 \mathrm{~mm}$, male $1.563 \pm 0.023 \mathrm{~mm}$ ) (fig. 4). The mean CL of mature males and females was significantly correlated with water temperature (Spearman's rank correlation coefficient, mature females: $n=11$, $r_{\mathrm{s}}=-0.809, p<0.01$; mature males: $\left.n=11, r_{\mathrm{s}}=-0.618, p<0.05\right)$. 


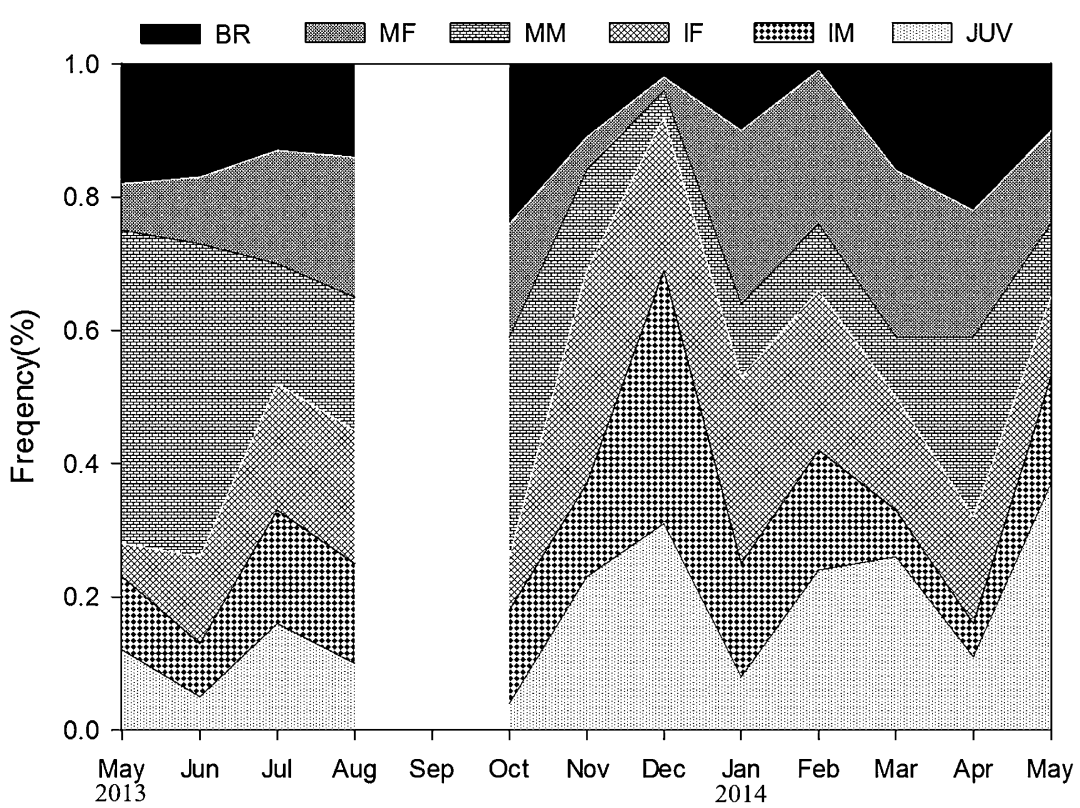

Fig. 3. Demographic structure of Neomysis nigra Nakazawa, 1910. shown by $\%$ frequency of individual number. JUV, juvenile; IF, immature female; IM, immature male; MM, mature male; MF, mature female; BR, brooding female.

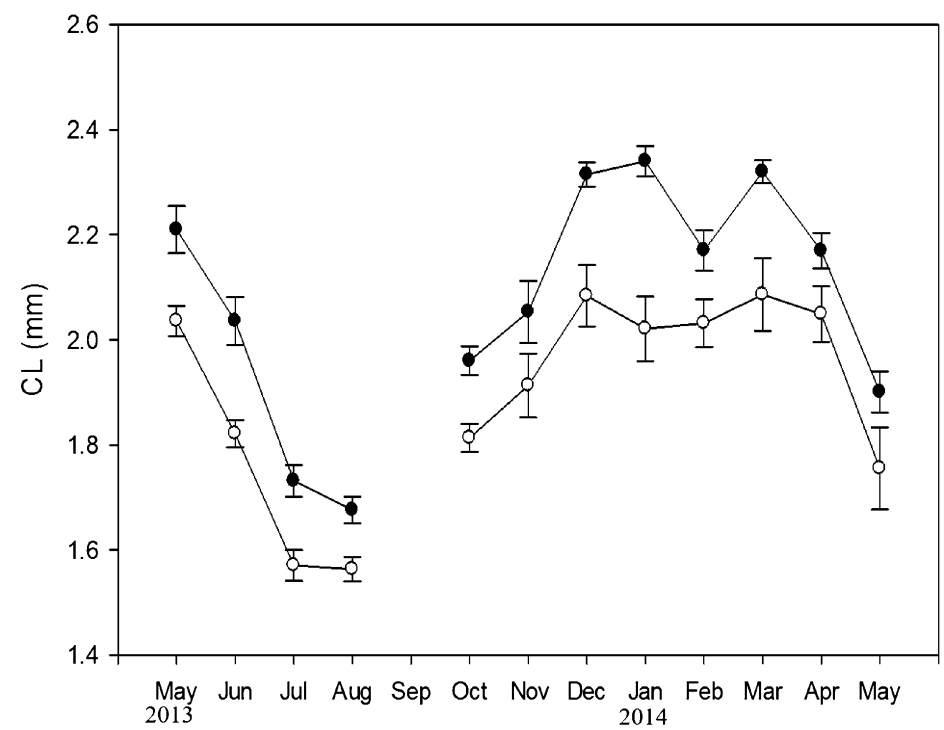

Fig. 4. Monthly variation of the mean size (CL) of mature females and males of Neomysis nigra Nakazawa, 1910. Black circles, mature females; open circles, mature males. 


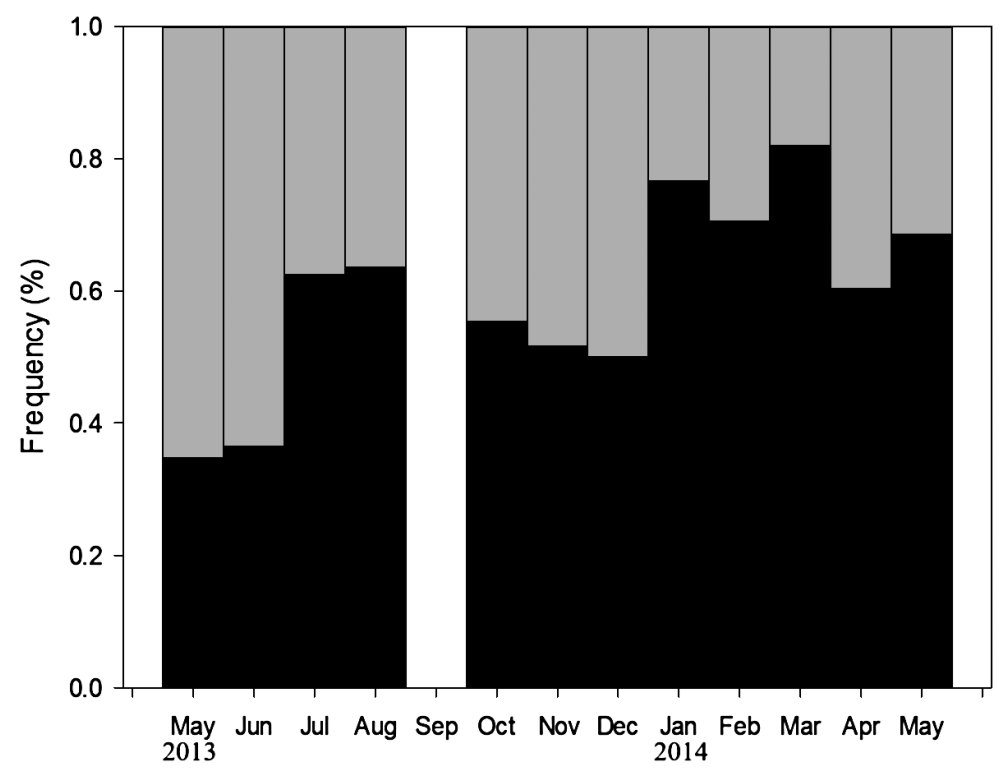

Fig. 5. Variations of sex ratio in Neomysis nigra Nakazawa, 1910 (number of mature males vs. number of mature females). Black bar, mature females; grey bar, mature males.

Sex ratio and size at sexual maturity

The sex ratio over the whole sampling period was 0.73 , with monthly variations ranging from 0.2 to 1.9 (fig. 5). The proportion of mature females was lower than that of mature males in May and June 2013 (0.35 and 0.36\%), whereas the proportion of mature females was higher than mature males in other months (more than 0.5\%). In March 2014, the proportion of mature females was the highest $(0.82 \%)$, differing significantly from a balanced sex ratio $\left(\chi^{2}\right.$ test, $\mathrm{df}=$ $\left.11, \chi^{2}=54.45, p<0.001\right)$. Females were more abundant than males in most of the sampling months. However, the sex ratio in each month was not significantly correlated with temperature or salinity (Spearman's rank correlation coefficient, temperature: $n=11, r_{\mathrm{s}}=-0.082, p=0.811$; salinity: $n=11, r_{\mathrm{s}}=-0.527$, $p=0.096)$.

The proportion of mature individuals was fitted to CL by logistic functions: $P_{\mathrm{m}}=1 /\left(1-\exp \left(7.06 \times C L_{\mathrm{m}}-11.44\right)\right)\left(r^{2}=0.976, p<0.01\right)$ for mature males and $P_{\mathrm{f}}=1 /\left(1-\exp \left(8.17 \times C L_{\mathrm{f}}-14.05\right)\right)\left(r^{2}=0.957, p<0.01\right)$ for mature females (including brooding females). The $50 \%$ sexual maturity size $\left(C L_{\mathrm{i}(50)}\right)$ was $1.62 \mathrm{~mm}$ for males and $1.72 \mathrm{~mm}$ for females.

\section{Population structure}

One or two modes of CL of $N$. nigra were found in all sampling months (fig. 6 and table I). Two modes were found in January 2014. The mean of the smaller 
(\%)
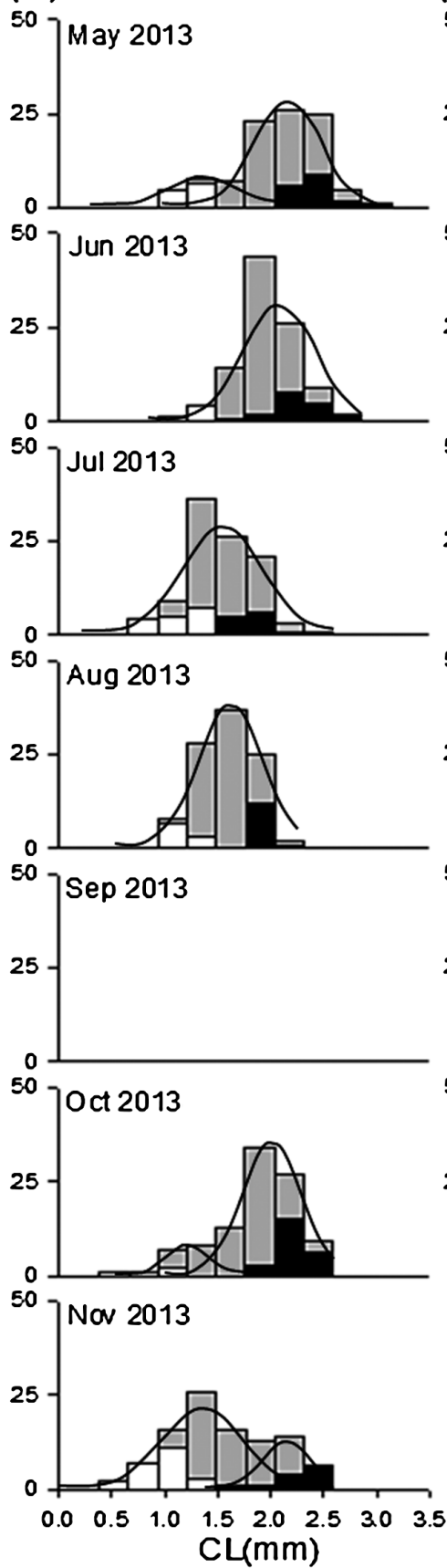

$(\%)$

50 jec 2013
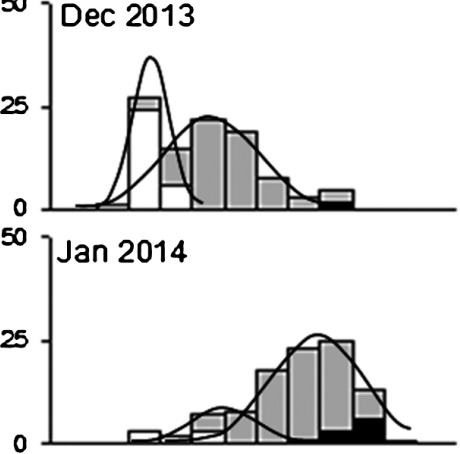

50 jFeb 2014

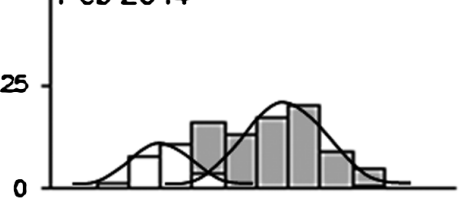

50 J Mar 2014

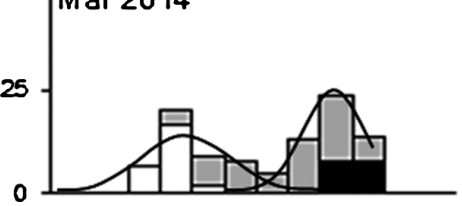

50 ] Apr 2014

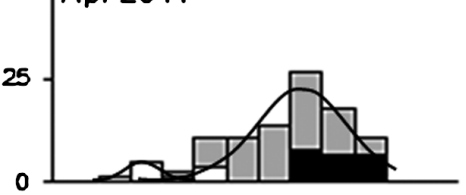

50 May 2014

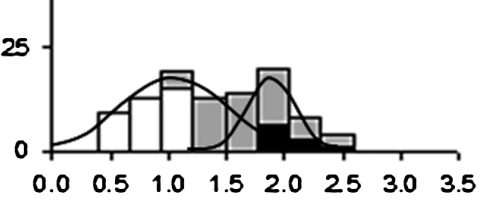

$\mathrm{CL}(\mathrm{mm})$

Fig. 6. Size frequency distributions of Neomysis nigra Nakazawa, 1910 from May 2013 to May 2014. White bar, juvenile; black bar, brooding females; grey bar, others. 


\section{TABLE I}

Neomysis nigra Nakazawa, 1910: Number of modes and CL (mean and standard deviation)

\begin{tabular}{lccc}
\hline Month & Mode & Mean $(\mathrm{mm})$ & SD \\
\hline May 2013 & 1 & 1.34 & 0.32 \\
June 2013 & 2 & 2.02 & 0.30 \\
July 2013 & 1 & 1.87 & 0.33 \\
August 2013 & 1 & 1.42 & 0.34 \\
October 2013 & 1 & 1.52 & 0.28 \\
November 2013 & 1 & 1.17 & 0.19 \\
& 2 & 1.88 & 0.24 \\
December 2013 & 1 & 1.26 & 0.34 \\
& 2 & 2.03 & 0.20 \\
January 2014 & 1 & 0.86 & 0.13 \\
February 2014 & 2 & 1.27 & 0.38 \\
March 2014 & 1 & 1.43 & 0.24 \\
April 2014 & 2 & 2.13 & 0.34 \\
& 1 & 0.95 & 0.19 \\
May 2014 & 1 & 1.85 & 0.34 \\
& 2 & 1.04 & 0.18 \\
& 1 & 2.26 & 0.29 \\
& 2 & 0.81 & 0.16 \\
& 1 & 2.03 & 0.44 \\
& 2 & 1.03 & 0.29 \\
& & 1.76 & 0.20 \\
\hline
\end{tabular}

mode was $1.43 \pm 0.24 \mathrm{~mm}$, and that of the larger mode was $2.13 \pm 0.34 \mathrm{~mm}$. The mode $(0.95 \pm 0.19 \mathrm{~mm})$ with the smallest CL was observed in February 2014, although there were very few brooding females in this mode. The smallest mode $(1.04 \pm 0.30 \mathrm{~mm})$ was found in March 2014. A small mode $(0.81 \pm 0.16 \mathrm{~mm})$ and a large mode $(2.05 \pm 0.24 \mathrm{~mm})$ co-occurred in April 2014. The mean of the small mode in May $2014(1.03 \pm 0.29 \mathrm{~mm})$ was larger than that of the small mode in April. In May 2013, the sizes of a small mode and a large mode were $1.34 \pm$ $0.32 \mathrm{~mm}$, and $2.02 \pm 0.30 \mathrm{~mm}$, respectively. Only one mode appeared in June, July and August 2013. The mean of the mode $(1.87 \pm 0.33 \mathrm{~mm})$ in June 2013 was larger than that of small mode in May 2013. The mean of the mode in July (1.42 \pm $0.34 \mathrm{~mm}$ ) was similar to that of August $2013(1.52 \pm 0.28 \mathrm{~mm})$. There were multimodes in October, November and December 2013. The mean of the smaller mode in October 2013 was $1.17 \pm 0.19 \mathrm{~mm}$, and that of the larger mode was $1.88 \pm$ $0.24 \mathrm{~mm}$. In November, the mean size of the small mode was $1.26 \pm 0.34 \mathrm{~mm}$ and that of the large mode was $2.03 \pm 0.20 \mathrm{~mm}$. A small mode $(0.86 \pm 0.13 \mathrm{~mm})$ and a large mode $(1.27 \pm 0.38 \mathrm{~mm})$ were present in December 2013 . 


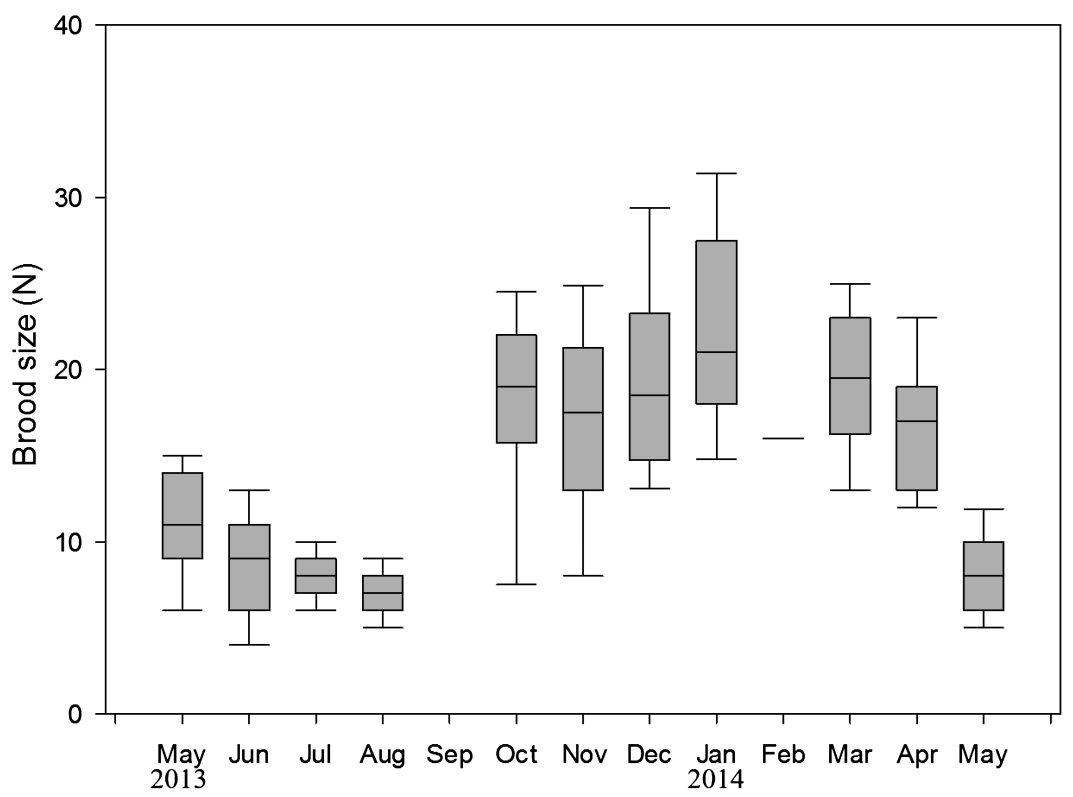

Fig. 7. Monthly variation in the mean brood size of brooding females in Neomysis nigra Nakazawa, 1910.

\section{Marsupial contents}

The number of embryos or larvae during the study period ranged between 1 and 36 individuals per marsupium (fig. 7). The mean brood size was highest in January 2014 (23.1 per marsupium), while it was lowest in August 2013 (7.66 per marsupium). The brood size was negatively correlated with water temperature, with CL lengths being larger in lower water temperature compared to higher water temperature. (Spearman's rank correlation coefficient, $r_{\mathrm{s}}=-0.733, p<0.01$.)

The log-transformed values of CL and number of embryos or larvae in the females with embryonic and nauplioid stages, except post-nauplioid stage, showed statistically significant linear relationships (embryonic stage: $n=141, r^{2}=0.432$, $p<0.001$; nauplioid stage: $n=250, r^{2}=0.148, p<0.001$; post-nauplioid stage: $n=39, r^{2}=0.034, p>0.260$ ). When larvae grew in the marsupium, the brood size of brooding females decreased (fig. 8). However, in the embryonic and nauplioid stage, the slopes of the regressions were significantly different (ANCOVA, $F=9.80$, df $=1, p<0.01$ ). The number of eggs or larvae in the embryonic and nauplioid stage was not significantly different.

\section{DISCUSSION}

The growth of mysids is related to water temperature. Juveniles grow almost linearly with temperature (Toda et al., 1984). However, adult size is correlated 


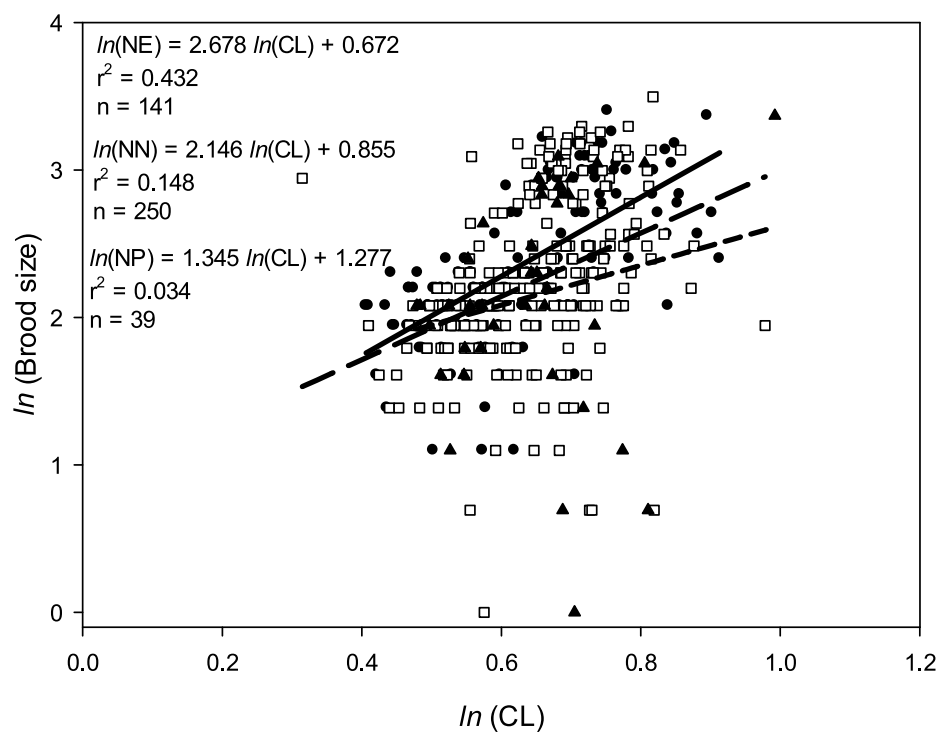

Fig. 8. Relationships between the CL of brooding females and the number of egg and larvae. NE, number of embryonic stage specimens; NN, number of nauplioid stage specimens; NP, number of post-nauplioid stage specimens; solid line, embryonic stage $(\bullet)$; long-dashed line, nauplioid stage $(\square)$; short-dashed line, post-nauplioid stage $(\boldsymbol{\Lambda})$.

inversely with temperature measured at that time. In temperate regions, small adult mysids are collected at higher water temperature in summer and large adult mysids are collected at lower temperature in winter (Toda et al., 1987; Lejeusne \& Chevaldonné, 2005; Sudo et al., 2011; Delgado et al., 2013). Similar results were reported for Neomysis americana (S. I. Smith, 1873), N. integer (Leach, 1814), N. japonica and N. awatschensis populations (Ishikawa \& Oshima, 1951; Pezzack \& Corey, 1979; Toda et al., 1982, 1984; Mees et al., 1994; Yamada et al., 2007). The occurrence of this phenomenon in $N$. nigra in the Ojo-ri embayment may have resulted from the relationship between water temperature and grow rate in the juvenile stage. The size of adult individuals collected during the warm period corresponded to that of young ones that grew up at a low growth rate during the cold period. By contrast, the individuals collected during the cold season have a smaller body size than those collected during the warmer season (Lejeusne \& Chevaldonné, 2005).

Temperature influences the fluctuations in mysid populations (Mauchline, 1980). The change of temperature induces the movement of mysids to escape from mass mortality or temperature shock (Kotta \& Kotta, 2001). Hemimysis lamornae mediterranea Bacescu, 1936 disappeared during July-August $\left(26.3^{\circ} \mathrm{C}\right)$ in the Ebro delta, followed by a subsequent increase in the number of individuals in autumn (Delgado et al., 2013). Neomysis integer also disappeared in the Gulf of Riga, due 
to the high temperature in summer (Kotta \& Kotta, 1999). Although N. awatschensis is considered a eurythermal mysid (Tattersall \& Tattersall, 1951), the upper lethal temperature range of this species is from 24.2 to $25.4^{\circ} \mathrm{C}$ (Hair, 1971). Neomysis awatschensis can migrate to other waters (Yamada et al., 2007). Probably, $N$. nigra may move to the surface or shallow water due to high temperatures in the Ojo-ri embayment in summer.

All species of mysids lay their eggs into a marsupium (Mauchline, 1980). In mysids, there is a strong positive correlation between the length of brooding females and their brood size (Mauchline, 1980; Toda et al., 1984), as there is between the length of brooding females and the water temperature. Large females result from an overwintering generation of mysids, while smaller females constitute the summer generation (Toda et al., 1982). Neomysis mirabilis (Czerniavsky, 1882 ) and $N$. integer are reported to have this relationship (Bremer \& Vijverberg, 1982; Yamada et al., 2007). N. awatschensis also has a linear positive relationship between brooding female size and brood size (Yamada et al., 2007). Thus, the brood size of $N$. nigra changes with seasonal variations of brooding female size, corresponding to the seasonal water temperature variations.

The water temperature is considered one of the main factors conditioning the occurrence and efficiency of recruitment and reproduction of mysids (Mauchline, 1980; Wittmann, 1984). Several mysids stop breeding during the winter due to the strong seasonal variation of water temperatures in some areas of the midlatitudes (Wittmann, 1984). The reproductive season of $N$. awatschensis was from March through November (Toda et al., 1982). This reproductive trend has also been reported in N. awatschensis of the north-western Pacific Ocean (Yan, 1982; Yamada et al., 2007). Continuous reproduction is a biological phenomenon in neritic mysids between 25 and $50^{\circ} \mathrm{N}$ (Pezzack \& Corey, 1979). In the case of $N$. nigra, the constant presence of brooding females and juveniles indicates that the species reproduces all year round (Pinheiro \& Fransozo, 2002).

The fluctuations of the sex ratio may be the result of migration, differences in the minimum size at which secondary sexual characteristics appear (Mauchline, 1980), different life duration or different rates of mortality among males and females (Hakala, 1978). In addition, the sex ratio of mysids is related to salinity. For example, Schistomysis kervillei (G. O. Sars, 1885) tends to have a decreasing proportion of females with increasing salinity (Rappé et al., 2011). Although the sex ratios within mysid populations are variable, the number of females frequently is higher than that of males (Mauchline, 1980). This higher proportion of females compared to males has been reported in mysids, such as $H$. l. mediterranea, Mesopodopsis orientalis (W. Tattersall, 1908) and Siriella clausii G. O. Sars, 1877 (Hanamura et al., 2008; Barberá et al., 2013; Delgado et al., 2013). The proportion 
of females in N. awatschensis is also higher than that of males (Toda et al., 1982; Yan, 1982).

The size at sexual maturity is a critical indicator of the reproductive capacity of a population. It may indicate a variation in the growth rate of many crustacean species (Street, 1969). Female mysids grow to be larger than males (Mauchline, 1980), due to more frequent moults in males combined with a slower growth rate. This different growth rate indicates that male sexual characteristics need to be distinguished at smaller sizes than females (Toda et al., 1987). The CL in females is positively related to a brood size, and large CL leads to high brood size (Toda et al., 1984). The smaller size of males compared to females serves fast mobility for getting females and reducing the risk of predation (Correa \& Thiel, 2003). Mysid males reach sexual maturity at a smaller size than females (Sudo, 2003; Fockedey et al., 2005), and our data agree with this general pattern.

Although reproduction occurs every month, the relative proportion of juveniles and brooding females characterises the spawning groups. In continuous reproduction, the different proportion of brooding females enables us to recognise peaks in some seasons (Pinheiro \& Fransozo, 2002). The occurrence of a spawning group in a species reproducing all year round indicates either the presence of more intensive periods of reproduction followed by intensive periods of breeding, or more intensive periods of recruitment (Lejeusne \& Chevaldonné, 2005). The relative proportion of $N$. awatschensis juveniles is more than 50\% from June to December (Yamada et al., 2007), and that of brooding females has several peaks from March and September (Toda et al., 1982). The time lag between maturation and the relative proportion of juveniles or brooding females was used to estimate the number of generations of $N$. awatschensis by Yan (1982) and Yamada et al. (2007). Neomysis awatschensis matures within 6 weeks in April-May and in 3 weeks in June (Toda et al., 1982), and grows to adult in $15-20$ days at $20-25^{\circ} \mathrm{C}$ and $20-30$ days at $15-20^{\circ} \mathrm{C}$ (Toda et al., 1984, 1987). However, $N$. awatschensis has a short generation time, and their brood interval decreases with increasing temperature (Murano, 1964; Toda et al., 1984, 1987). This short generation time indicates that field studies should consider short time scales for the estimation of the number of generations of warm-water species. A total of 19 overlapping cohorts of Orientomysis robusta (Murano, 1984) were observed over an annual cycle (Sudo et al., 2011). Their findings are based on weekly samplings and growth rates determined in the laboratory. As a result, our monthly samples were not sufficient to explain the number of generations of $N$. nigra.

In conclusion, $N$. nigra is characterized by a small size at sexual maturity of males, high proportion of females, continuous reproduction and four major spawning groups all year round. Population structure and life history of $N$. nigra are mainly influenced by water temperature. These ecological features of $N$. nigra 
are close to those of $N$. awatschensis. However, the precise number of generations of $N$. nigra remains unknown. To clarify this problem, weekly samplings and laboratory rearing experiments should be conducted.

\section{ACKNOWLEDGEMENTS}

The authors would like to thank Sum Rho for support in sampling. The authors would also like to thank the anonymous referees for valuable comments that have greatly improved this article. This research was a part of the project entitled "Longterm change of structure and function in marine ecosystems of Korea", funded by the Ministry of Oceans and Fisheries, Korea. This research was funded by the Korea Institute of Marine Science and Technology Promotion.

\section{REFERENCES}

AfFAN, M. A. \& J. LEE, 2004. Seasonal characteristics of phytoplankton dynamics and environmental factors in the coast of Mara-do and U-do, Jeju Island, Korea. Algae, 19: 235-245.

Baldó, F., L. J. TARAcido, A. M. Arias \& P. DRAKe, 2001. Distribution and life history of the mysid Rhopalophthalmus mediterraneus in the Guadalquivir estuary (SW Spain). J. Crust. Biol., 21: 961-972.

Barbera, C., P. Sanchez-Jerez \& J. C. Sorbe, 2013. Population structure and secondary production of Siriella clausii, a dominant detritus feeding mysid in Posidonia oceanica meadows (W Mediterranean Sea). Estuar. Coast. Shelf Sci., 131: 103-116.

BRAndT, A., 1999. On the origin and evolution of Antarctic Peracarida (Crustacea, Malacostraca). Sci. Mar., 63(Suppl. 1): 261-274.

BREMER, P. \& J. ViJVERBERG, 1982. Production, population biology and diet of Neomysis integer (Leach) in a shallow Frisian lake (The Netherlands). Hydrobiologia, 93: 41-51.

CAmpbell, A., 1985. Application of a yield and egg-per-recruit model to the lobster fishery in the Bay of Fundy. N. Am. J. Fish. Manage., 5: 91-104.

CorreA, C. \& M. Thiel, 2003. Mating systems in caridean shrimp (Decapoda: Caridea) and their evolutionary consequences for sexual dimorphism and reproductive biology. Rev. Chil. Lit., 76: $187-203$.

Delgado, L., G. Guerao, C. San Vicente \& C. Ribera, 2013. Population structure and life history of Hemimysis lamornae mediterranea (Malacostraca: Mysida) in the Ebro Delta (NW Mediterranean). J. Sea Res., 83: 137-145.

Fockedey, N. \& J. MeEs, 1999. Feeding of the hyperbenthic mysid Neomysis integer in the maximum turbidity zone of the Elbe, Westerschelde and Gironde estuaries. J. Mar. Syst., 22: 207-228.

Fockedey, N., J. Mees, M. Vangheluwe, T. Verslycke, C. R. Janssen \& M. Vincx, 2005. Temperature and salinity effects on post-marsupial growth of Neomysis integer (Crustacea: Mysidacea). J. Exp. Mar. Biol. Ecol., 326: 27-47.

HAIR, J. R., 1971. Upper lethal temperature and thermal shock tolerances of the opossum shrimp (Neomysis awatschensis) from the Sacramento-San Joaquin Estuary, California. Calif. Fish Game, 57: 17-27.

HAKAlA, I., 1978. Distribution, population dynamics and production of Mysis relicta (Lovén) in southern Finland. Ann. Zool. Fennici, 15: 243-258. 
Hanamura, Y., R. Siow \& P. E. Chee, 2008. Reproductive biology and seasonality of the Indo-Australasian mysid Mesopodopsis orientalis (Crustacea: Mysida) in a tropical mangrove estuary, Malaysia. Estuar. Coast. Shelf Sci., 77: 467-474.

HolmQuist, C., 1973. Taxonomy, distribution and ecology of the three species Neomysis intermedia (Czerniavsky), N. awatschensis (Brandt) and N. mercedis Holmes (Crustacea, Mysidacea). Zool. Jb. Syst., 100: 197-222.

Hwang, D., Y. LeE \& G. KIM, 2005. Large submarine groundwater discharge and benthic eutrophication in Bangdu Bay on volcanic Jeju Island, Korea. Limnol. Oceanogr., 50: 13931403.

II, N., 1964. Fauna Japonica. Mysidae (Crustacea): i-x, 1-610. (Biogeographical Society of Japan, Tokyo).

IshiKaWA, M. \& Y. OSHima, 1951. On the life-history of a mysid crustacean, Neomysis japonica Nakazawa. Bull. Jap. Soc. Sci. Fish., 16: 461-472.

JEE, J. H., U. G. HwANG \& J. C. KANG, 2003. Effects of salinity on survival, growth and oxygen consumption rates in the mysid, Neomysis awatschensis. Korean J. Environ. Biol., 21: 66-71.

KotTA, I. \& J. KotтA, 1999. Distribution and migration of mysids in the Gulf of Riga (northern Baltic). Proc. Estonian Acad. Sci. Biol. Ecol., 48: 284-295.

- $-\&-\ldots, 2001$. Distribution of mysids on bank slopes in the Gulf of Riga. Proc. Estonian Acad. Sci. Biol. Ecol., 50: 14-21.

LAPRISE, R. \& J. J. DODSON, 1993. Nature of environmental variability experienced by benthic and pelagic animals in the St. Lawrence Estuary, Canada. Mar. Ecol. Prog. Ser., 94: 129-139.

LEE, S., 2006. Distribution of seagrass and its ecological importance of Jeju Island, Korea. (Final Report for MAB Young Scientist Award).

Lejeusne, C. \& P. Chevaldonné, 2005. Population structure and life history of Hemimysis margalefi (Crustacea: Mysidacea), a 'thermophilic' cave-dwelling species benefiting from the warming of the NW Mediterranean. Mar. Ecol. Prog. Ser., 287: 189-199.

Mauchline, J., 1980. The biology of mysids and euphausiids. Part one. The biology of mysids. Adv. Mar. Biol., 18: 1-369.

MCKenney, C. L., JR. \& D. M. Celestial, 1995. Interactions among salinity, temperature, and age on growth of the estuarine mysid Mysidopsis bahia reared in the laboratory through a complete life cycle. I. Body mass and age-specific growth rate. J. Crust. Biol., 15: 169-178.

MeEs, J., Z. AbDUlKerim \& O. HAMERLYNCK, 1994. Life history, growth and production of Neomysis integer in the Westerschelde estuary (SW Netherlands). Mar. Ecol. Prog. Ser., 109: 43-57.

Murano, M., 1964. Fisheries biology of a marine relict mysid Neomysis intermedia Czerniawsky. IV. Lifecycle, with special reference to the reproduction of the mysid. The Aquaculture, Japan, 12: $109-117$.

$\mathrm{OH}, \mathrm{H}$. S., 2004. A study on the management of migratory bird sanctuary and the status of water bird migration on JeJu Island. Korean J. Ornithol., 11: 11-32.

Pavlyuk, O. N. \& Y. A. Trebukhova, 2011. Intertidal meiofauna of Jeju Island, Korea. Ocean Sci. J., 46: 1-11.

PetryasheV, V., 2002. Leptostraca, Mysidacea, Isopoda, and Decapoda (Anomura) (Crustacea, Malacostraca) of the Chukchi Sea and adjacent waters: biogeography and fauna formation. Russ. J. Mar. Biol., 28: S56-S63.

Petryashev, V. V. \& M. E. Daneliya, 2014. The taxonomic status of western Pacific mysid species of Neomysis awatschensis (Brandt, 1851) group. Russ. J. Mar. Biol., 40: 165-176.

PeZzack, D. S. \& S. Corey, 1979. The life history and distribution of Neomysis americana (Smith) (Crustacea, Mysidacea) in Passamaquoddy Bay. Can. J. Zool., 57: 785-793.

- _ \& — - 1982. Effects of temperature and salinity on immature and juvenile Neomysis americana (Smith) (Crustacea; Mysidacea). Can. J. Zool., 60: 2725-2728. 
Pinheiro, M. A. A. \& A. Fransozo, 2002. Reproduction of the speckled swimming crab Arenaeus cribrarius (Brachyura: Portunidae) on the Brazilian coast near $23^{\circ} 30^{\prime}$ S. J. Crust. Biol., 22: 416-428.

Rappé, K., N. Fockedey, C. van Colen, A. Cattrijsse, J. Mees \& M. Vincx, 2011. Spatial distribution and general population characteristics of mysid shrimps in the Westerschelde estuary (SW Netherlands). Estuar. Coast. Shelf Sci., 91: 187-197.

Street, R. J., 1969. The New Zealand crayfish, Jasus edwardsii (Hutton 1875). (Tech. Rep. 30, N.Z. Marine Department Fish.).

Sturges, H. A., 1926. The choice of a class interval. J. Am. Statist. Assoc., 21: 65-66.

SUDO, H., 2003. Effect of temperature on growth, sexual maturity and reproduction of Acanthomysis robusta (Crustacea: Mysidacea) reared in the laboratory. Mar. Biol., 143: 1095-1107.

Sudo, H., N. KaJihara \& M. NoguCHI, 2011. Life history and production of the mysid Orientomysis robusta: high $P / B$ ratio in a shallow warm-temperate habitat of the Sea of Japan. Mar. Biol., 158: 1537-1549.

Tattersall, W. M. \& O. S. Tattersall, 1951. The British Mysidacea. (The Ray Society, London).

Toda, H., T. Arima, M. TAkahashi \& S. IChimura, 1987. Physiological evaluation of temperature effect on the growth processes of the mysid, Neomysis intermedia Czerniawsky. J. Plankton Res., 9: 51-63.

Toda, H., M. TAKahashi \& S. IChimura, 1982. Abundance and life history of Neomysis intermedia Czerniawsky in Lake Kasumigaura. Hydrobiologia, 93: 31-39.

— _ , — — \& — , 1983. Diel vertical movement of Neomysis intermedia Czerniawsky (Crustacea, Mysidacea) population in a shallow eutrophic lake. Jpn. J. Limnol., 44: 277-282.

- _ , _ — \& _ - 1984. The effect of temperature on the post-embryonic growth of Neomysis intermedia Czerniawsky (Crustacea, Mysidacea) under laboratory conditions. J. Plankton Res., 6: $647-662$.

WitTMANN, K. J., 1981. On the breeding biology and physiology of marsupial development in Mediterranean Leptomysis (Mysidacea: Crustacea) with special reference to the effects of temperature and egg size. J. Exp. Mar. Biol. Ecol., 53: 261-279.

- -1984 . Ecophysiology of marsupial development and reproduction in Mysidacea (Crustacea). Oceanogr. Mar. Biol. Annu. Rev., 22: 393-428.

Yamada, K., K. Takahashi, C. Vallet, S. Taguchi \& T. Toda, 2007. Distribution, life history, and production of three species of Neomysis in Akkeshi-ko estuary, northern Japan. Mar. Biol., 150: 905-917.

YAN, Z., 1982. On the biology of Neomysis awatschensis (Crustacea, Mysidacea) I. Population and reproduction characteristics. Oceanologia et Limnologia sinica, 1: 66-77.

Ysebaert, T. \& P. M. J. Herman, 2002. Spatial and temporal variation in benthic macrofauna and relationships with environmental variables in an estuarine, intertidal soft-sediment environment. Mar. Ecol. Prog. Ser., 244: 105-124.

First received 30 October 2014.

Final version accepted 11 November 2015. 